\title{
Green silicone elastomer obtained from a counterintuitively stable mixture of glycerol and PDMS
}

\author{
Mazurek, P.; Hvilsted, S.; Skov, A. L.
}

Published in:

Polymer

Link to article, DOI:

10.1016/j.polymer.2016.01.070

Publication date:

2016

Document Version

Peer reviewed version

Link back to DTU Orbit

Citation (APA):

Mazurek, P., Hvilsted, S., \& Skov, A. L. (2016). Green silicone elastomer obtained from a counterintuitively stable mixture of glycerol and PDMS. Polymer, 87, 1-7. https://doi.org/10.1016/j.polymer.2016.01.070

\section{General rights}

Copyright and moral rights for the publications made accessible in the public portal are retained by the authors and/or other copyright owners and it is a condition of accessing publications that users recognise and abide by the legal requirements associated with these rights.

- Users may download and print one copy of any publication from the public portal for the purpose of private study or research.

- You may not further distribute the material or use it for any profit-making activity or commercial gain

- You may freely distribute the URL identifying the publication in the public portal

If you believe that this document breaches copyright please contact us providing details, and we will remove access to the work immediately and investigate your claim. 


\section{elsevier_JPOL_18422}

\section{Green silicone elastomer obtained from a counterintuitively stable mixture of glycerol and PDMS}

P. Mazurek

S. Hvilsted

A.L. Skov*

al@kt.dtu.dk

Danish Polymer Centre, Department of Chemical and Biochemical Engineering, Building 227, Technical University of Denmark, DK-2800 Kgs. Lyngby, Denmark

*Corresponding author.

\section{Abstract}

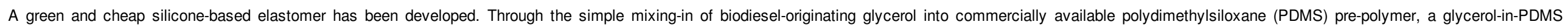

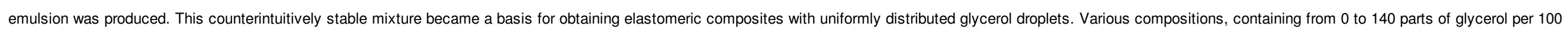

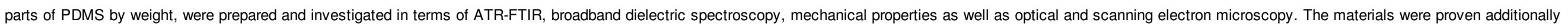

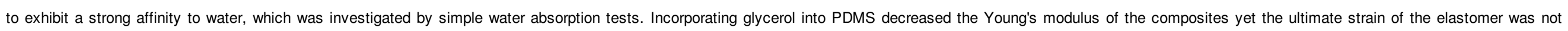
compromised, even in the presence of very high loadings. The conducted experiments highlight the great potential of this new type of elastomer and reveal some possible applications.

Keywords: PDMS; Silicone; Glycerol; Filler; Emulsion; Elastomer; Green; Eco; Absorption; Release

\section{Introduction}

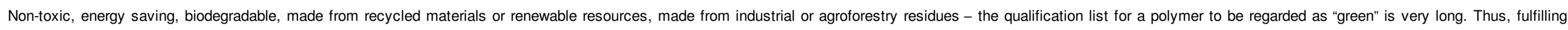

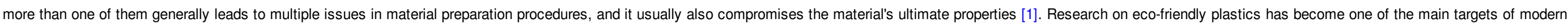

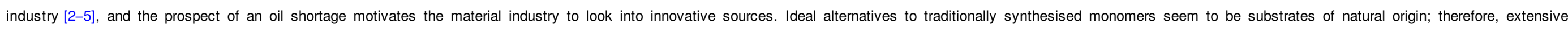

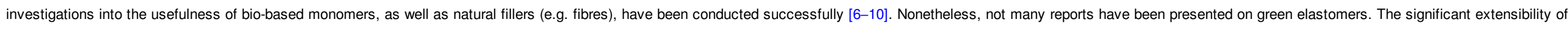

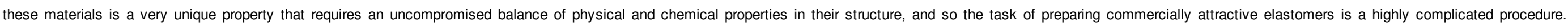

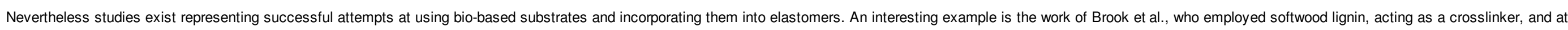

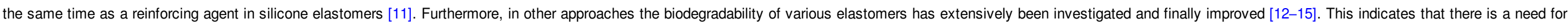
developing green elastomers, although the preparation procedures still require further optimisation.

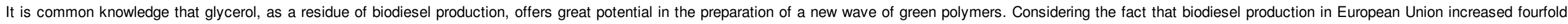

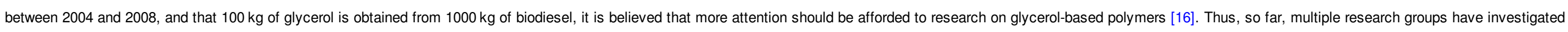

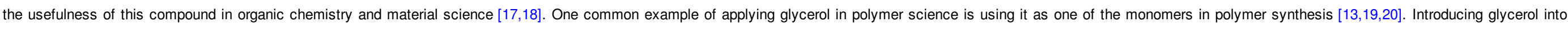

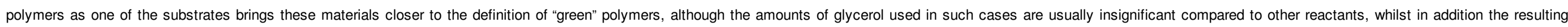
polymers become significantly more expensive.

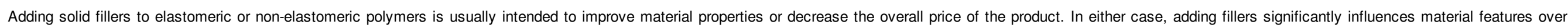

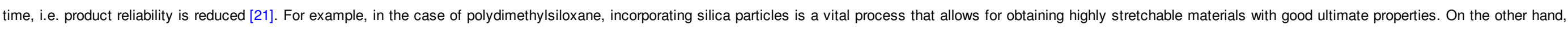

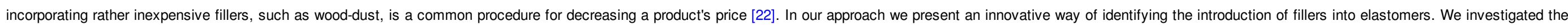




\section{elsevier_JPOL_18422}

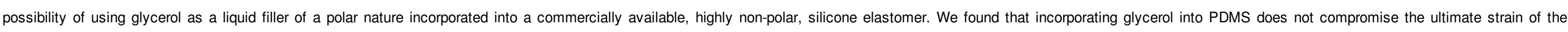

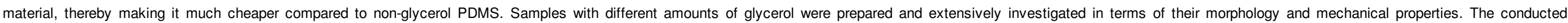
experiments revealed and finally proved the great potential of this new type of green and cheap elastomer.

\section{Experimental}

\subsection{Materials}

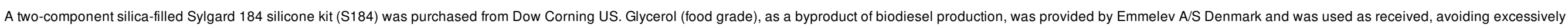
long contact with the air

\subsection{Methods}

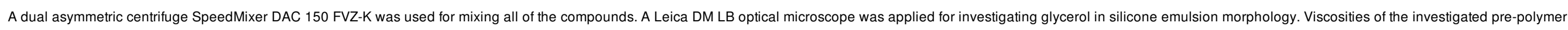

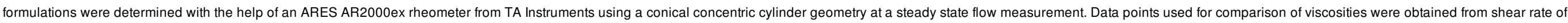

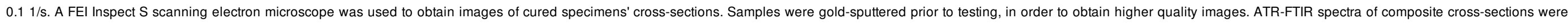

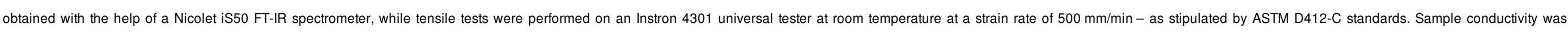
investigated with a Novocontrol broadband dielectric spectrometer. Disc samples, $20 \mathrm{~mm}$ in diameter and $1 \mathrm{~mm}$ thick, were tested in frequency ranges between $10^{6}$ and $10^{-1} \mathrm{~Hz}$.

\subsection{Sample preparation}

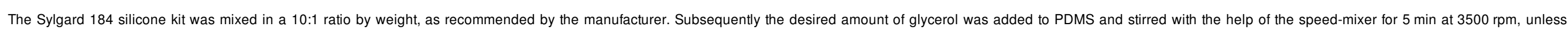

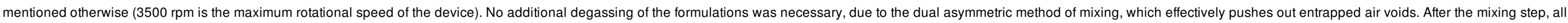

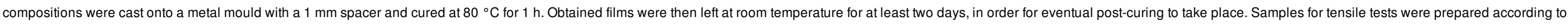
ASTM D412-C standards. Mixed formulations were cast onto a PMMA plate with a $3 \mathrm{~mm}$ spacer. After curing, the samples were cut with a custom-made die.

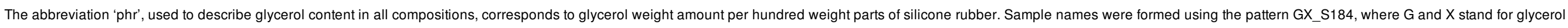
and glycerol phr added to a PDMS prepolymer, respectively. Intuitively S184 corresponds to the applied PDMS system.

\section{Results and discussion}

\subsection{Glycerol in PDMS emulsions and the morphology of cured samples}

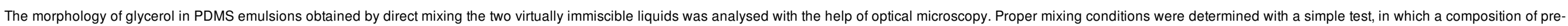

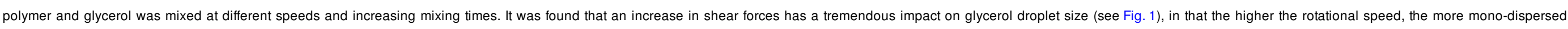

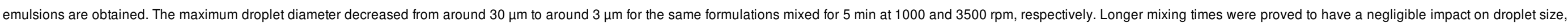

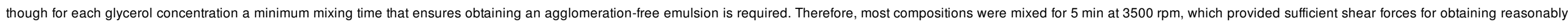

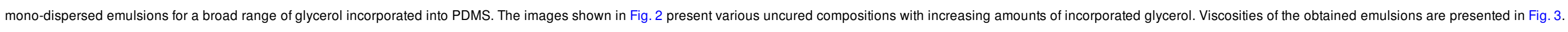
Produced mixtures were stable for extensive amounts of time. No change in droplet size was observed, even several hours after mixing. 


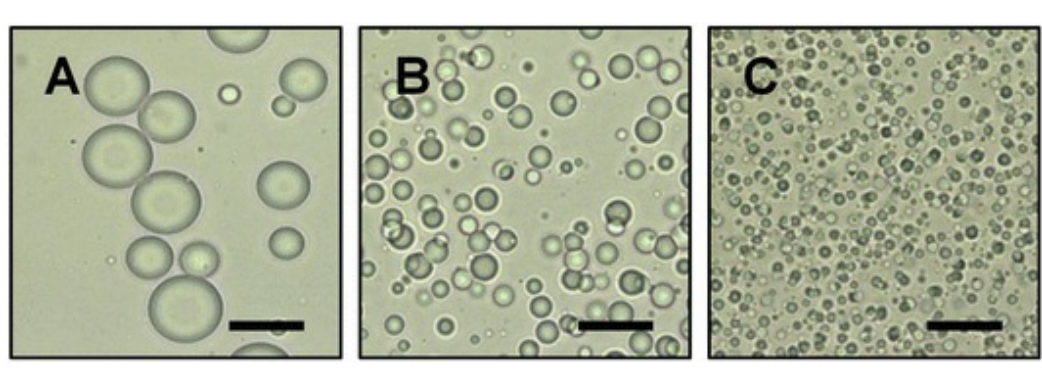

Fig. 1 Optical microscopy images of 10 phr glycerol in S184 emulsions obtained after 5 min of speed-mixing at 1000 (A), 2000 (B) and 3500 (C) rpm. Scale bars for all images correspond to $25 \mu \mathrm{m}$.

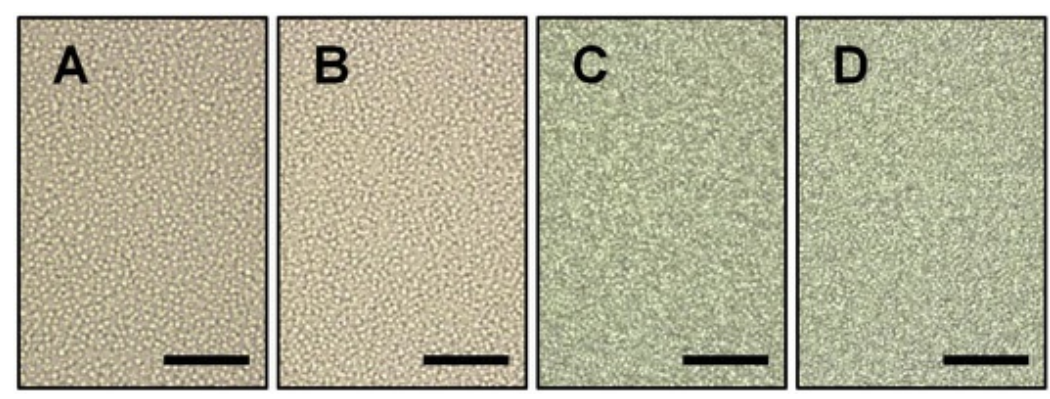

Fig. 2 Optical microscopy images of glycerol in PDMS emulsions. A - $10 \mathrm{phr}, \mathrm{B}-40 \mathrm{phr}, \mathrm{C}-70 \mathrm{phr}, \mathrm{D}-100 \mathrm{phr}$. Scale bars for all images correspond to $50 \mu \mathrm{m}$.

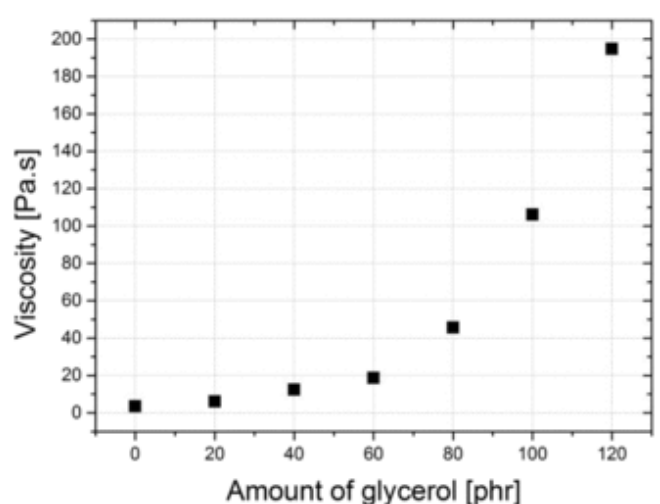

Fig. 3 Viscosities of various glycerol-Sylgard 184 formulations.

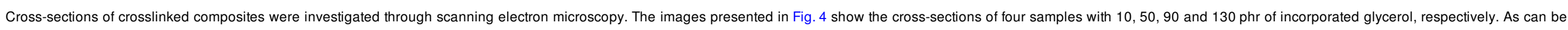

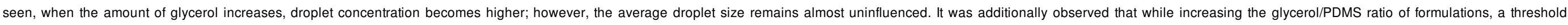

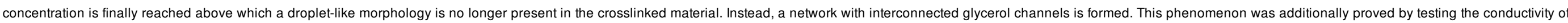

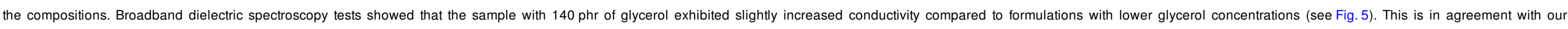

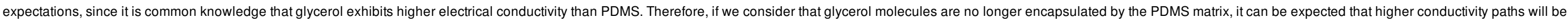

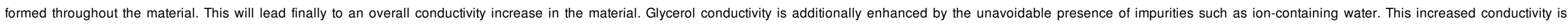
considered as a direct indication of the formation of a bicontinuous phase in the elastomer. 


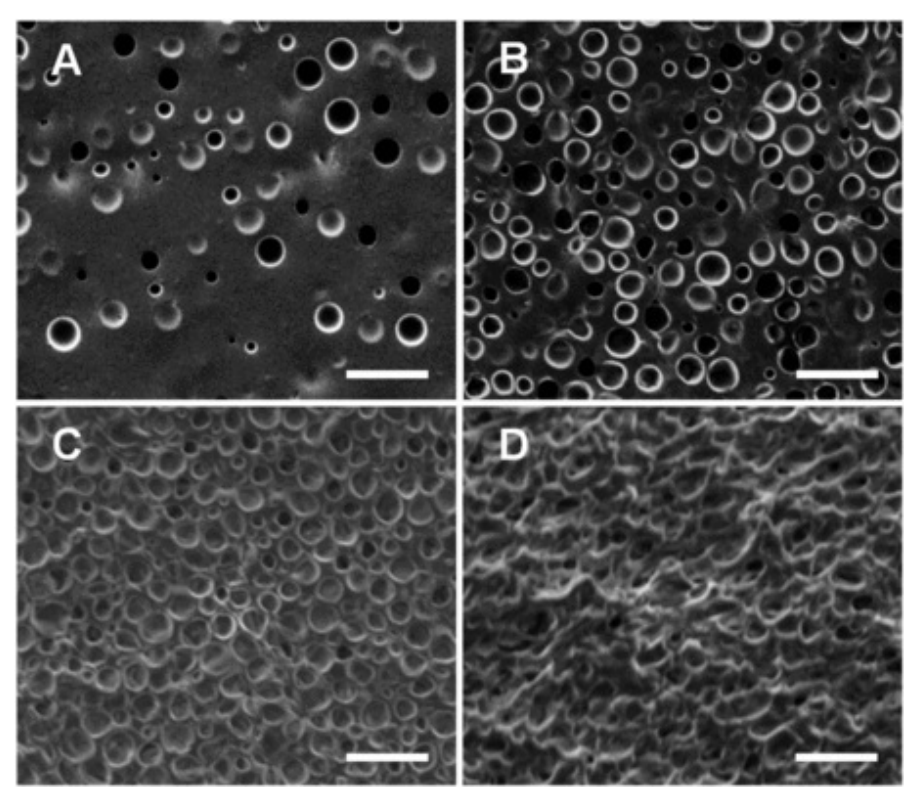

Fig. 4 SEM images of cured glycerol-PDMS composite cross-sections. A - $10 \mathrm{phr}, \mathrm{B}-50 \mathrm{phr}, \mathrm{C}-90 \mathrm{phr}, \mathrm{D}-130 \mathrm{phr}$ of glycerol. Scale bars for all images correspond to $10 \mu \mathrm{m}$.

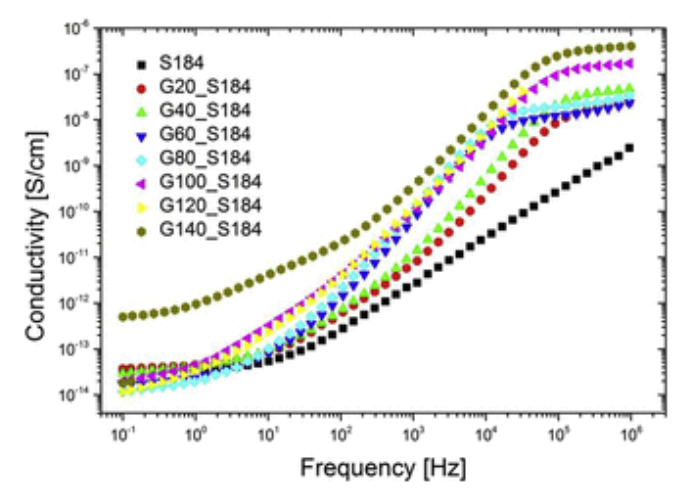

Fig. 5 Conductivity of various glycerol-PDMS compositions presented as a function of frequency.

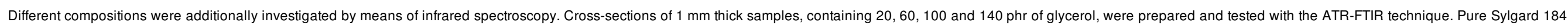

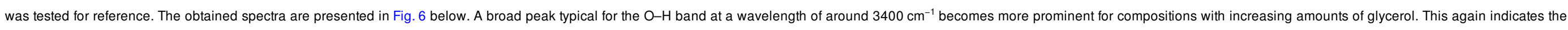
high efficiency of glycerol encapsulation within the PDMS matrix and proves that glycerol remains in the sample. 
elsevier_JPOL_18422

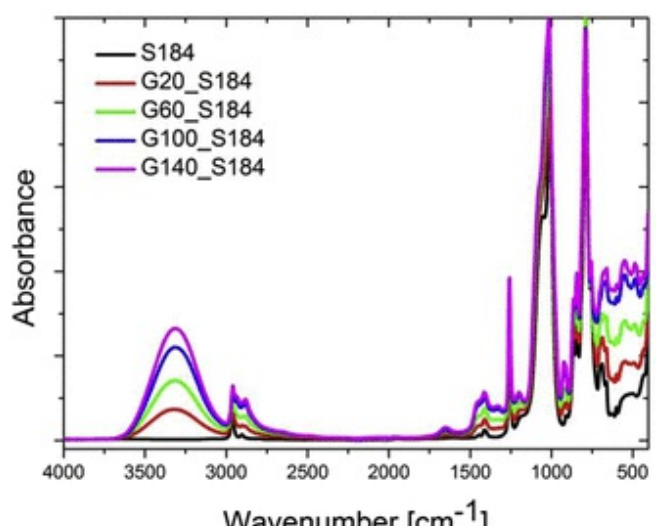

Fig. 6 ATR-FTIR spectra of various glycerol-PDMS composite cross-sections.

\subsection{Water absorption}

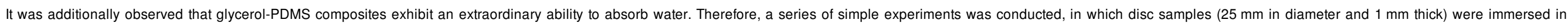

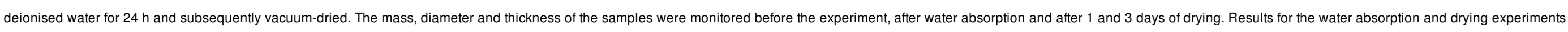

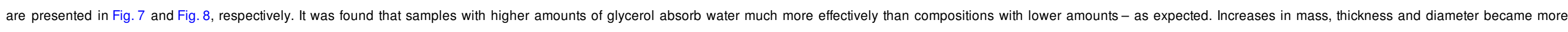

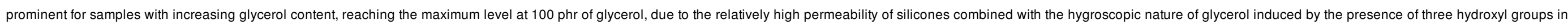

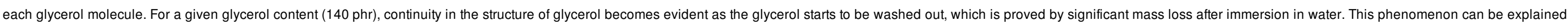

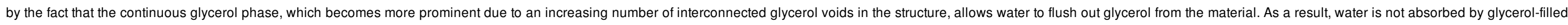
voids and consequently the sample's mass increases only slightly or even - as in the case of the highest concentration - decreases.

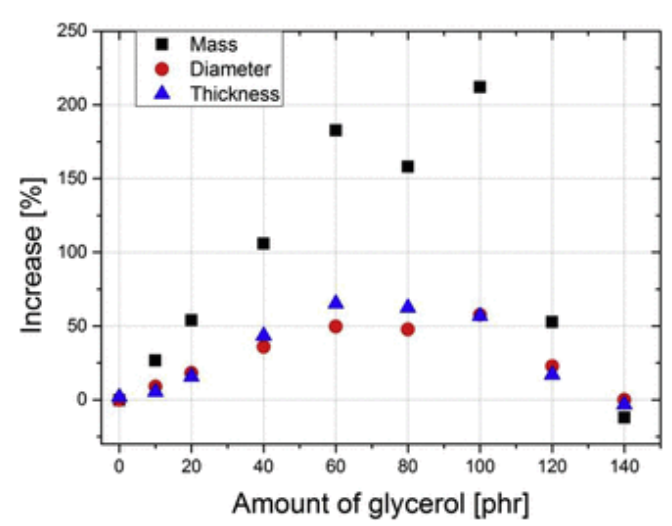

Fig. 7 Mass, diameter and thickness changes of various glycerol-PDMS formulations caused by water absorption. 


\section{elsevier_JPOL_18422}

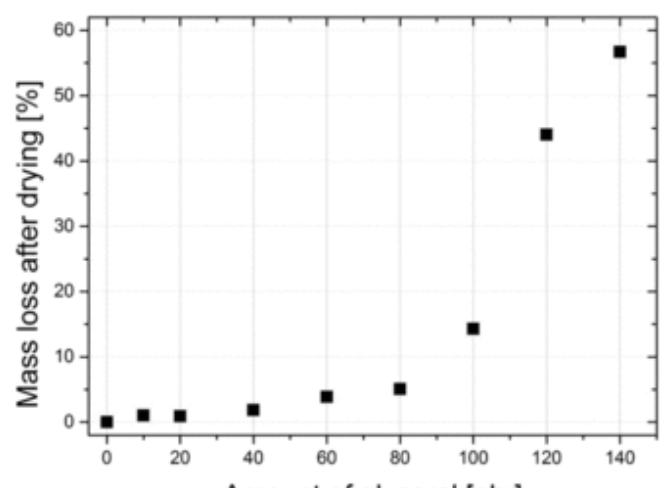

Amount of glycerol [phr]

Fig. 8 Mass losses of various glycerol-PDMS formulations after 3 days' drying, resulting from water absorption experiments.

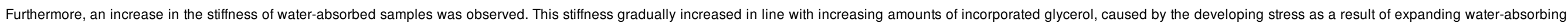

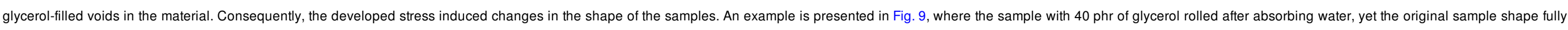
recovered after drying.

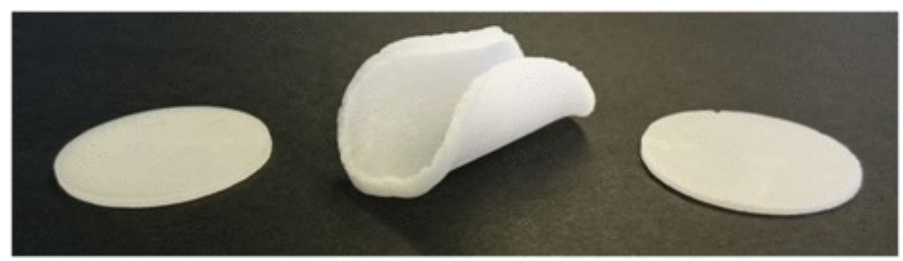

Fig. 9 Images of a $25 \mathrm{~mm}$ in diameter and $1 \mathrm{~mm}$ thick sample, G40_S184, before the absorption experiment, after absorption and after drying, respectively.

\subsection{Dried materials}

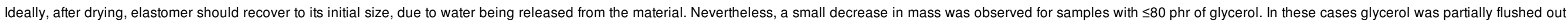

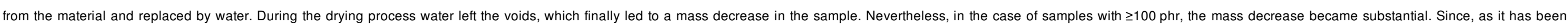

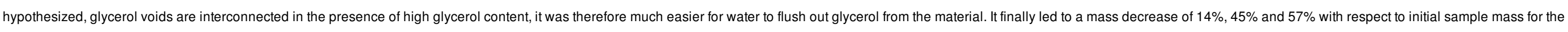

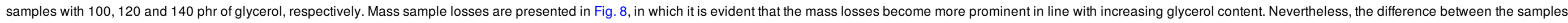

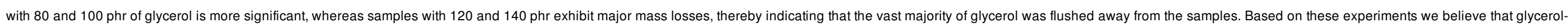
PDMS composites can be applied, for example, as a tool for controlled drug delivery, where adjustable release velocity is required.

\subsection{Tensile tests}

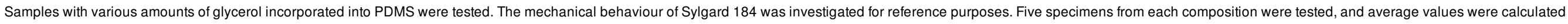

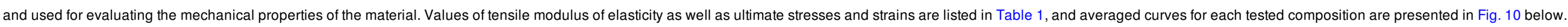

Table 1 Mechanical properties of various glycerol-Sylgard 184 compositions obtained from tensile measurements.

\begin{tabular}{|c|c|c|c|c|}
\hline \multirow[t]{2}{*}{ Sample } & \multicolumn{2}{|c|}{ Tensile modulus of elasticity [MPa] } & \multirow[t]{2}{*}{ Strain at break [\%] } & \multirow[t]{2}{*}{ Stress at break [MPa] } \\
\hline & Tangent $(\mathrm{Y})$ & Secant $\left(Y_{100}\right)$ & & \\
\hline S184 & 1.07 & 3.66 & 154 & 8.29 \\
\hline
\end{tabular}




\section{elsevier_JPOL_18422}

\begin{tabular}{|c|c|c|c|c|}
\hline G20_S184 & 0.80 & 2.58 & 160 & 6.19 \\
\hline G40_S184 & 0.58 & 1.76 & 166 & 4.60 \\
\hline G60_S184 & 0.51 & 1.55 & 168 & 4.04 \\
\hline G80_S184 & 0.43 & 1.32 & 161 & 3.17 \\
\hline G100_S184 & 0.38 & 1.14 & 159 & 2.71 \\
\hline G120_S184 & 0.33 & 0.97 & 116 & 1.30 \\
\hline
\end{tabular}

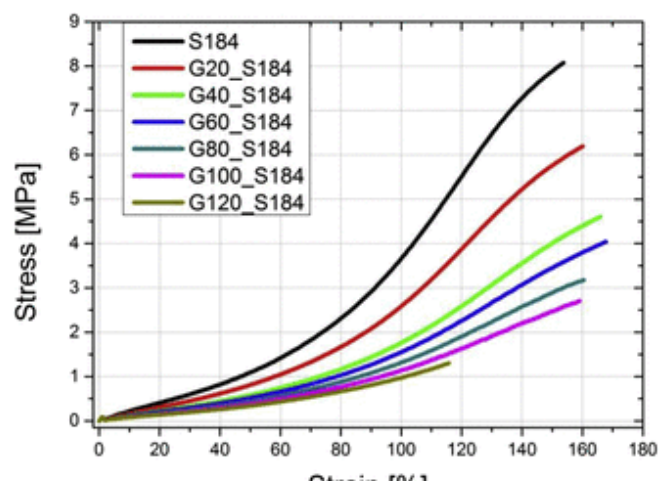

Strain [\%]

Fig. 10 Stress-strain behaviour of various compositions obtained from tensile measurements.

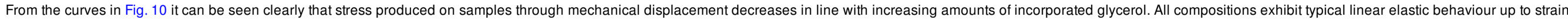

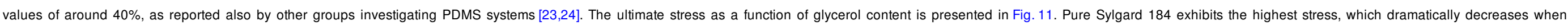

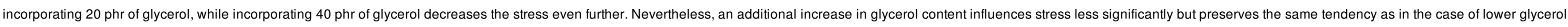

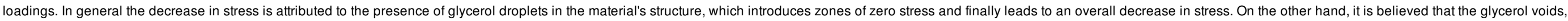

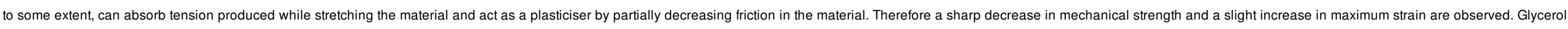

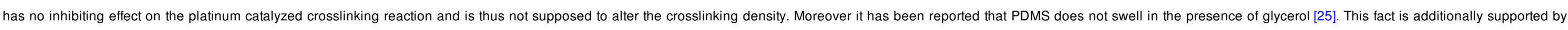

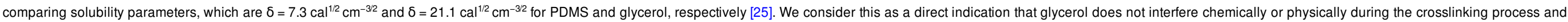
that ultimate composite properties are not influenced thereupon.

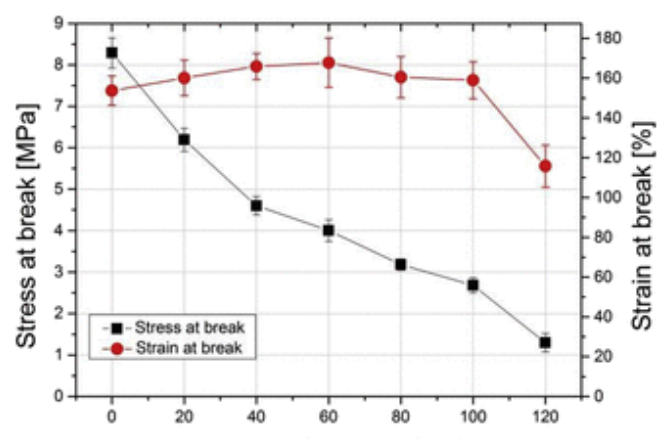

Amount of glycerol [phr]

Fig. 11 Ultimate properties of various glycerol-S184 compositions. 


\section{elsevier_JPOL_18422}

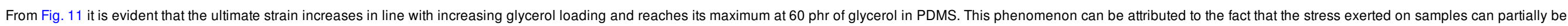

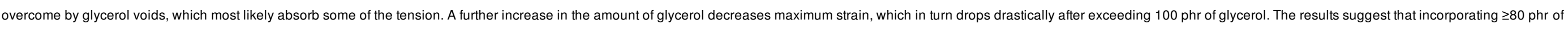
glycerol negatively influences material integrity, which is not significant for samples with 80 and $100 \mathrm{phr}$ of glycerol but becomes prominent at $120 \mathrm{phr}$ of glycerol.

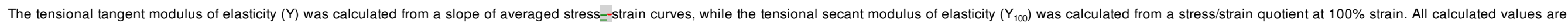

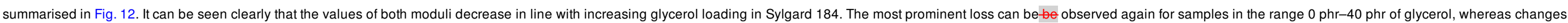
in moduli at higher loadings are less substantial, which is in agreement with previous observations.

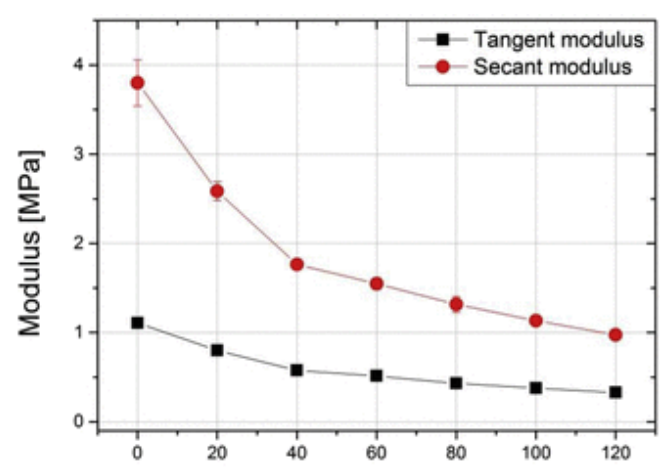

Amount of glycerol [phr]

Fig. 12 Tensional tangent $(Y)$ and secant $\left(Y_{100}\right)$ moduli of elasticity of various glycerol-S184 compositions.

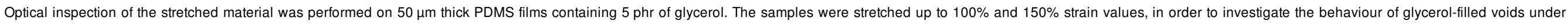

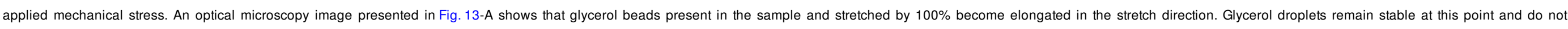

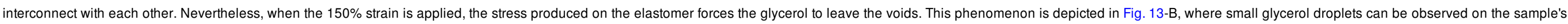

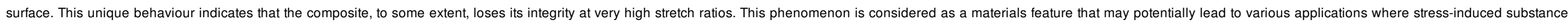
release is required.

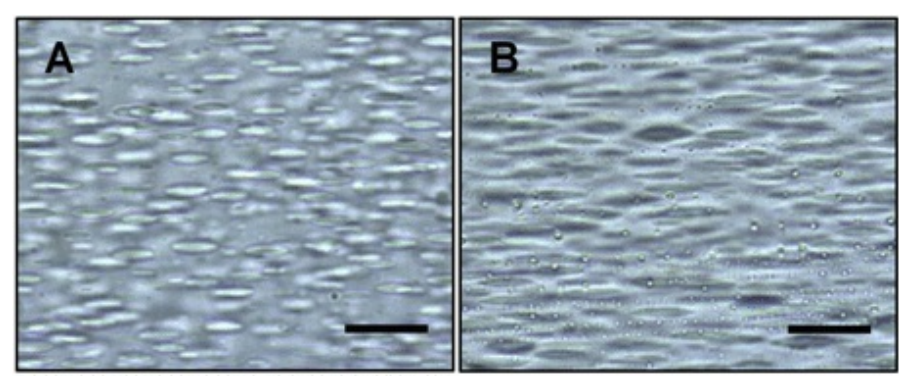

Fig. 13 Optical microscopy images of stretched glycerol-PDMS composites (5 phr). A - 100\% strain, B - 150\% strain. Scale bars for all images correspond to $25 \mu \mathrm{m}$.

\section{Conclusions}

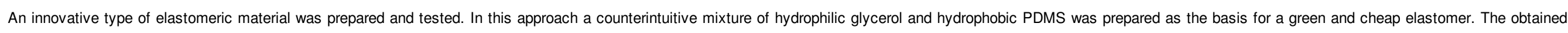

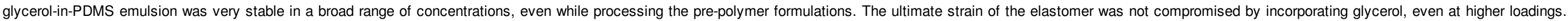

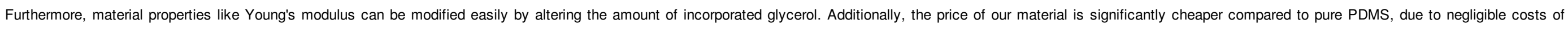
glycerol as a by-product in biodiesel production. Considering that the glycerol contents described herein substantially exceed 100\% by weight, the material's overall price can be reduced at least twofold. 


\section{elsevier_JPOL_18422}

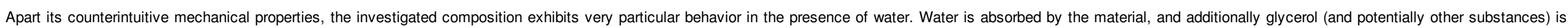

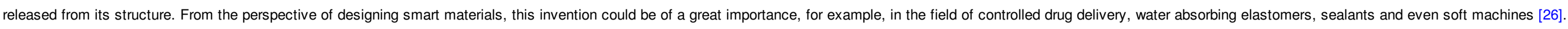

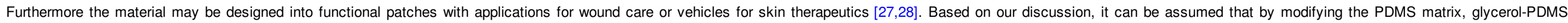
composites can exhibit different release velocities which can potentially lead to broadening the application spectrum.

\section{Acknowledgements}

The authors acknowledge funding from Innovationsfonden Denmark.

\section{References}

[1]

C. Cazan and A. Duta, Advances in Elastomers I, 2013, Springer; Berlin.

[2]

K. Madhavan Nampoothiri, N.R. Nair and R.P. John, Bioresour. Technol. 101, 2010, 8493-8501.

[3]

S.S. Ray and M. Bousmina, Prog. Mater. Sci. 50, 2005, 962-1079.

[4]

M. Avella, A. Buzarovska, M.E. Errico, G. Gentile and A. Grozdanov, Materials 2, 2009, 911-925.

[5]

T. Mekonnen, P. Mussone, K. Alemaskin, L. Sopkow, J. Wolodko, P. Choi and D. Bressler, J. Mater. Chem. A 1, 2013, 13186.

[6]

G. Mehta, A.K. Mohanty, M. Misra and L.T. Drzal, Green Chem. 6, 2004, 254-258.

[7]

N. Supanchaiyamat, P.S. Shuttleworth, A.J. Hunt, J.H. Clark and A.S. Matharu, Green Chem. 14, 2012, 1759-1765.

[8]

H.S. Kim, H.J. Kim, J.W. Lee and I.G. Choi, Polym. Degrad. Stab. 91, 2006, 1117-1127.

[9]

E. Chiellini, P. Cinelli, V.I. Ilieva and M. Martera, Biomacromolecules 9, 2008, 1007-1013.

[10]

Y. Sun, L. Yang, X. Lu and C. He, J. Mater. Chem. A 3, 2015, 3699-3709.

[11]

J. Zhang, Y. Chen, P. Sewell and M.A. Brook, Green Chem. 17, 2015, 1811-1819.

[12]

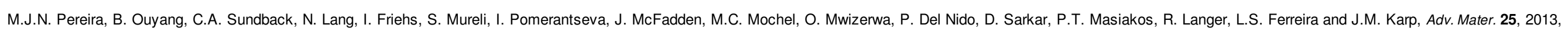
1209-1215. 


\section{elsevier_JPOL_18422}

[13]

Y. Wang, G.A. Ameer, B.J. Sheppard and R. Langer, Nat. Biotechnol. 20, 2002, 602-606.

[14]

B.G. Amsden, G. Misra, F. Gu and H.M. Younes, Biomacromolecules 5, 2004, 2479-2486.

[15]

R. Singh and A.J. Varma, Green Chem. 14, 2012, 348-356.

[16]

A. Takagaki, K. Iwatani, S. Nishimura and K. Ebitani, Green Chem. 12, 2010, 578-581.

[17]

B. Katryniok, H. Kimura, E. Skrzyńska, J.S. Girardon, P. Fongarland, M. Capron, R. Ducoulombier, N. Mimura, S. Paul and F. Dumeignil, Green Chem. 13, 2011, 1960-1979.

[18]

C. Della Pina, E. Falletta and M. Rossi, Green Chem. 13, 2011, 1624-1632.

[19]

A. Celli, P. Marchese, S. Sullalti, C. Berti, G. Barbiroli, S. Commereuc and V. Verney, Green Chem. 14, 2012, 182-187.

[20]

T. Mekonnen, P. Mussone, H. Khalil and D. Bressler, J. Mater. Chem. A 1, 2013, 13379-13398.

[21]

S. Zakaria, L. Yu, G. Kofod and A.L. Skov, Mater. Today Commun. 4, 2015, 204-213.

[22]

S. Sa'adon and A.Z.M. Rus, Appl. Mech. Mater. 465-466, 2014, 1039-1043.

[23]

I.D. Johnston, D.K. McCluskey, C.K.L. Tan, M.C. Tracey and J. Micromech, Microeng 24, 2014, 035017.

[24]

A.L. Larsen, K. Hansen, P. Sommer-Larsen, O. Hassager, A. Bach, S. Ndoni and M. Jørgensen, Macromolecules 36, 2003, 10063-10070.

[25]

J.N. Lee, C. Park and G.M. Whitesides, Anal. Chem. 75, 2003, 6544-6554.

[26]

D. Yang, B. Mosadegh, A. Ainla, B. Lee, F. Khashai, Z. Suo, K. Bertoldi and G.M. Whitesides, Adv. Funct. Mater. 27, 2015, 6323-6327.

[27]

T.G. Kim, H. Shin and D.W. Lim, Adv. Funct. Mater. 22, 2012, 2446-2468.

[28]

I.C. Liao, F.T. Moutos, B.T. Estes, X. Zhao and F. Guilak, Adv. Funct. Mater. 23, 2013, 5833-5839. 


\section{elsevier_JPOL_18422}

Graphical abstract

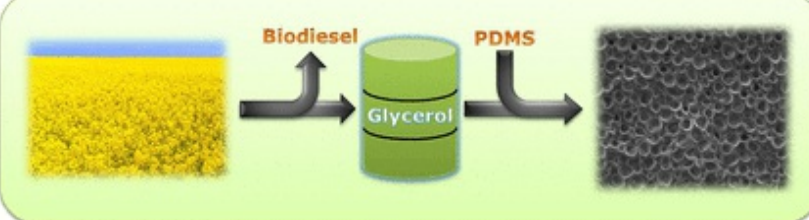

Highlights

- A novel two-phase glycerol-silicone elastomer is presented.

- Glycerol is incorporated into PDMS in a form of discrete droplets.

- The resulting composite can be considered as ecological and inexpensive.

- The inclusion does not affect significantly the ultimate strain of the elastomer.

- The composites exhibit very particular behaviour in the presence of water.

\section{Queries and Answers}

Query: Please provide the grant number for 'Innovationsfonden' if any.

Answer: none

Query: Please confirm that given names and surnames have been identified correctly.

Answer: Yes

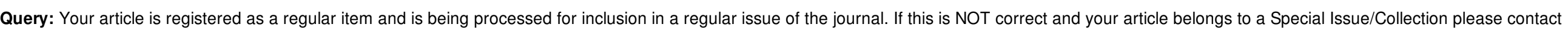
a.seedhouse@elsevier.com immediately prior to returning your corrections.

Answer: Yes 